\title{
HUMAN CAPITAL MANAGEMENT AND ACCOUNTABILITY OF SOCIAL ENTERPRISE
}

\author{
Siti Anis Nadia Abu Bakar*, Roshayani Arshad ${ }^{1}$, Nur Farahah Mohd Pauzi, Siti Nurulhuda \\ Mamat, Norliza Omar ${ }^{2}$ \\ *Faculty of Accountancy, Universiti Teknologi MARA Melaka \\ ${ }^{1}$ Accounting Research Institute, Faculty of Accountancy, Universiti Teknologi MARA \\ ${ }^{2}$ Faculty of Accountancy, Universiti Teknologi MARA Puncak Alam
}

\begin{abstract}
The emergence of social business enterprises has been attributed to the increased demand for sustainability among the non-profit organisations (NPOs) due to diminishing funding from traditional sources and increased competition for the scarce resources. To date, there is growing interest on social businesses (SBs) as innovation in providing public services that contributes to the social wellbeing of community. This in turn can be linked directly or indirectly to economic development as the sustainability level of the country is measured specifically towards the development of human capital and solving the social problems rather than the economics alone. Indeed, having both economic and non-economic aims, SBs would be the potential solutions to address a range of societal issues and increase the efficiency and quality of public sector services that focus on equitable growth with ecological sustainability. Therefore, it is important to explore the relationship between capability of SBs and the social impact created. This paper explores on capability based on human capital management and social impact or value created through SBs. This is expected to provide some insights on the sustainability and credibility of SBs to support the government efforts in moving towards high nation income.
\end{abstract}

Keywords: Social Enterprise, Human Capital, Accountability

\section{INTRODUCTION}

There was no clear, consensual definition of social enterprise in the literature (Hackett, 2010) and there is no consistently applied definition of social enterprise. In fact, it appears that each discipline or field defines social enterprise in its own image or view. Indeed different authors have used the label to apply to a wide range of different organisational types which has rendered conceptualisation problematic (Simmons, 2008).

Social entrepreneurship emerges as a response to the complex society needs whereby the concept of social entrepreneurship has been rapidly emerging in the private, public and nonprofit sectors over the last few years, and has embarked growing interest in social entrepreneurship as a whole (Johnson, 2000). Besides, it is a global phenomenon for social entrepreneurship to employ their innovative approaches to solve social problems which ultimately giving impact to the whole society (Robinson, Mair and Hockerts, 2009). Research on social enterprise has been gaining prominence in recent years and attracting attention in a number of different disciplines.

Sustainable development refers to the process whereby improvement is undertaken in such a way that interests of various stakeholders of nature and diverse social groups including future

*Corresponding author's email:ctanisnadia@melaka.uitm.edu.my 
generations are protected and preserved. It deals with presenting our nature of the present country to our future generations and at the same time taking care of socio-economic interests of all sections of society. Sustainability is not a new concept as its roots from a growing economic of the country. However, the level of sustainability of the country is measured not only in terms of economics alone, but for developing countries the human capital aspect also plays an important role as the qualities of the generation become a major contributor to the country's development. Over the recent years, English governments have promoted social enterprise and social entrepreneurship as potential solutions to address a range of societal issues and to increase the efficiency and quality of public sector services and economy outcome (Hall, Miller and Millar, 2012).

Tapsell and Woods (2010) offer a working definition of social entrepreneurship as follows: "the construction and pursuit of opportunities for transformative social change through innovative activities occurring within or across economic and social communities in a historical and cultural context". Furthermore, social enterprise is a new concept of applying business expertise and market-based skills such as developing innovative approaches, selling products and offering services in trading business in order to generate income (Jiao, 2011). This is also supported by (Rajput and Chopra, 2014) stating that the economies all over the world are realising that if we are somehow able to revert back to our original commercial path by taking up activities involving manpower rather than machines, our sustainability efforts shall be paced up.

In the context of social enterprises or social organizations, efficiency might well imply that many such organisations exist to deliver social and other community services cheaper than the public sector. They allow for cost savings by having volunteers as they have lower overheads count. An alternative effectiveness perspective might contend that their purpose is to deliver these services better, perhaps higher in quality, faster, more flexibly than a bureaucratic public sector by embracing entrepreneurial people in smaller and leaner organisations (Thompson, 2011). Therefore, it is important to develop and apply social entrepreneurship to sustain social development and enhance human capital.

However, some scholars consider the mission when defining social entrepreneurship. For instance, Dees (2001) believed that social entrepreneurs play the role of change agents in the social sector, by adopting a mission to create and sustain social value (not just private value), recognizing and relentlessly pursuing new opportunities to serve that mission, engaging in a process of continuous innovation, adaptation and learning, acting boldly without being limited by resources currently in hand and exhibiting heightened accountability to the constituencies served and for the outcomes created. Therefore, social value is the most important factor in this process although social entrepreneurship is often viewed as business with a social purpose that earns income for the non-profit sector. Furthermore, Dees (2003) said he leaned toward another definition of social entrepreneurship, one that emphasized innovation and impact, not income, in dealing with social problems. Much of the early social enterprise literature has focused on defining social enterprises, and adapting theories to explain their recent emergence.

\section{DRIVING TOWARDS SOCIAL ENTREPRENEURSHIP}

The concept of entrepreneurship that has emerged earlier has been modernized to emphasis on social change. As a consequence, social entrepreneurship has emerged to become subject of interest to many researchers in the present days. It is driven to the fact that not only individuals 
are having entrepreneurship spirit but they are also aiming towards helping the society voluntarily instead of going solely for figures.

The emergence of social enterprises in East Asian countries is closely linked to the socioeconomic changes of the late 1990s and to the early attempts of civil society organisations to cope with new social problems. As far as public authorities are concerned, they began to pay attention to those new initiatives as they had to consider new policy measures and programmes to meet the growing welfare needs (Defourny \& Kim,2011).

Apart from that, Defourny (2001) in his writing mentioned three principles that define social sector; one related to human capital being priority on the redistribution of profit to people and workforce over capital. Moreover, in terms of control over the management, social economy environment refers to one where a democratic structure will be taking place. Members are equally involved in the decision making process and have a say in any accounting and administrative matter (Defourny, 2001). This evidenced the development in human skills which is one element of human capital.

In another study setting, Jiao (2011) constructed a social model where sustaining social development and improve human well-being as a key success factor developed from the application of social entrepreneurship activity. It has been highlighted in the paper that social entrepreneurs will be knowledgeable because they emphasize the benefit of end-beneficiary which is the community. They will have the skills in understanding the customers on their needs and to then satisfy them in innovative way. Social business also develops the capability of the human in resource utilization skills. Social entrepreneurship impact had attracted increased attention. People find social entrepreneurs job are compelling as this job offers these extraordinary people with creativity and innovative ideas in producing goods and services. The interest in social entrepreneurship signals a transformed change in the elements of human capital namely, knowledge, ability to integrate and utilize resource and development of skills.

There were many researches carried out on these voluntary organizations looking at different way. Defourny (2001) looked at certain behavioral features of enterprises to be called social. Taking 15 European Union (EU) countries as sample, four features were identified from the study; 1) continuous production of goods and services, 2) high degree of autonomy, 3) operation with economic risk via own funding and 4) workers are either volunteers or minimum paid workers. On the other hand, Overall et al. (2010) discussed the concept of cultural context which led to the emergence of social entrepreneurship. The study in one local Maori social enterprise brought the idea that reconnecting the Maori people to their communities in sustaining culture through innovations from the Young Maori by providing roadmaps in New Zealand created the spirit of social entrepreneurship.

There were really a wide range of diverse opinions about social entrepreneurship. Yu (2011) studied the motivation factors toward the success of social enterprises in China considering the tight state control ruled by the government. They pointed out that the government's newly effort to privatize public services, the initiative taken by the third sector in probing socioeconomic problems, the spirit of private firms engaging in corporate social responsibility and foreign players' interest over social business fostering the kind of entrepreneurship activity. Meanwhile, Sodhi and Tang (2011) narrowed down the concept of social entrepreneurship towards creating business for the poor and help them via enabling good supply chain. The paper was drawn from the exploring of success social enterprises in Asia, South Africa, United States and many more. Apart from that, Hall et al. (2012) explored the motives of public sector 
to reform into social enterprise from health care perspective. Respondent of the study viewed social business as strategic improvement to deliver different kind of clinical and management services which could not happen in a bureaucratic public sector.

Cook and Inman (2012), on the other hand, discussed the success and loophole in some of the voluntary sectors for conservation in England. Without denying the social good of volunteering, they also highlighted issues on underfunding, task allocation, independence and potential undermining of labour market. However, Moreau and Mertens (2013) undertook different way of researching on social enterprise. They have developed a management competency model of social enterprise to ensure effective handling of this so-called social business. They were of the view that competency in social enterprise arise from competency in knowledge, skills and behaviour. Scholars have recognized the business move towards social entrepreneurship which makes social enterprise relationship very clear. Despite its increasing attention, has come concern over why exactly social entrepreneurs do

\section{HOW DOES SOCIETY BENEFIT?}

Social enterprise aims at solving social problems. The concept lies in this entrepreneurship differentiate their motives from public and private sector at large. Many studies highlighted concern raised in social business that any surplus generated from the so-called entrepreneurship activity must go back to the society, rather than keeping them solely within the owners and shareholders. Engelke, Mauksch, Darkow and Gracht (2015) conducted qualitative discussions involving experts in Germany about the development of social enterprise as problem solving solution in industrialized countries. They viewed social business as enterprise where profit stays in the business to support for social objectives. Jiao (2011) proposed that greater level of social entrepreneurship is positively related to society's social impact. Social business promotes social value where the application of the entrepreneurship is to be aligned with the need to solve social problem like the unemployment and the environment matters.

A study by Cheng (2015) asserted that social enterprises in Cambodia have emerged from critiques raised upon their non-governmental organizations (NGOs). The NGOs were seen as defeating their purpose where the poor still remains where they were, stressing over own financial survival and they have lowering the level of trust by the government. Furthermore, Daya (2014) also explored the social enterprise craft industry in the South Africa, focusing on how these entrepreneurs saved the poor and black women in particular and issues revolving them. Additionally, Sawmy (2015) explored the concept of inclusive business in extractive industry to sustain the business. The social business model implies the need to include the poor in the business chain to accommodate their corporate social responsibility by way of link them as local business partners, hire them as employees or create them as business producers.

Numerous papers stressed that helping the society are forces behind the emergence of social enterprise. Connolly and Kelly (2011) on his view about third sector and social sector explained that social sector defined their business where social objective are the central of their activities and reject any personal gain. A survey done with the service users of a social enterprise engaging in rural transportation highlighted the significant contribution that this service made to the residents. O'Shaughnessy, Casey and Enright (2011) found that elder residents mostly benefited from the social service; easy access to health care services, shops and post offices, removed the feeling of being isolated from other people, eliminate dependency on surrounding people to travel and many more. Researchers are on the idea that social entrepreneurs are more 
fascinated towards probing social problems. Social problems can be caused by social market failure too. Hackett (2010) discussed on the ability of social enterprise in eliminating unemployment, poverty, income gap of the society caused by failure in market that ordinary business failed to address. On its basic level, there is something appealing about social enterprise in driving social change which is to improve people's lives.

\section{CONCLUSION}

In recent years, we noticed a remarkable growth in the third sector. Social enterprise through its entrepreneurial activities is a mechanism in improving social value by reconciling the gaps in wealth which ultimately would influence the development of human capital and solve the social problem. In this paper, we reviewed literatures to specifically clarify the inconsistencies definition of social entrepreneurship that emerge from many thoughts and views. Then, we discussed the factors that initiated entrepreneurship that could benefit the society at large and also its relationship in developing the human capital. Finally, we discussed the consequences of social entrepreneurship to the society.

The government support for the entrepreneurship activities is really meaningful towards the effort of expanding social capital of social entrepreneur that can lead to a more harmonious society. The combination of different stakeholders in the social enterprise organizations that are more oriented could benefit the whole community (Defourny, 2001). This is vital importance to understand what social enterprise explicitly could bring in relation to the development of human capital who could be maintained as long term asset as the qualities of them become a major contributor to the organization and community at large.

Apart from that, given the increasing roles and profile, social enterprise is inextricably as the potential solutions to address a range of societal issues (Hall et al., 2012). Meanwhile, creating the opportunities for the poor is absolutely enabling good supply chain (Sodhi and Tang, 2011) that is essential to support sustainability efforts (Rajput and Chopra, 2014). The entrepreneurship by the social business requires proactive approaches whereby its application should be aligned in dealing with solving social problem like the unemployment issue in order to promote social value (Jiao, 2011) and as the main key to measure the social impact as a whole.

\section{REFERENCES}

Cheng, I. H. (2015), Re-modelling and Reconceptualising Skills Development in Cambodia: How are Social Enterprises Preparing Young People for Successful Transitions between Learning and Work? International Journal of Educational Development, Vol. 43, pp.134141.

Connolly, C. and Kelly, M. (2011), Understanding Accountability in Social Enterprise Organisations: A Framework. Social Enterprise Journal, Vol.7 No.3, pp. 224-237.

Connolly, C. and Kelly, M. (2011), Understanding Accountability in Social Enterprise

Organisations: A Framework, Social Enterprise Journal, Vol. 7 No. 3, pp. 224-237. 
Cook, H. and Inman, A. (2012), The Voluntary Sector and Conservation for England: Achievements, Expanding Roles and Uncertain Future, Journal of Environmental Management, Vol. 112, pp. 170-177.

Daya, S. (2014), Saving the Other: Exploring the Social in Social Enterprise, Geoforum, Vol. 57, pp. 120-128.

Dees, G. J. (2001), The Meaning of Social Entrepreneurship, Available at: www.caseatduke.org/documents/dees_sedef.pdf.

Dees, G. J. (2003), New Definitions of Social Entrepreneurship: Free Eye Exams and Wheelchair Drivers, Knowledge@Wharton Newsletter, Vol. 12 No.10, pp. 3-16.

Defourny, J. (2001), From Third Sector to Social Enterprise, The Emergence of Social Enterprise, London and New York, Routledge, pp. 1-28.

Defourny.J and Kim.S.Y (2011), Emerging models of social enterprise in Eastern Asia: a crosscountry analysis, Social Enterprise Journal Vol. 7 No. 1, 2011,pp. 86-111.

Engelke, H., Mauksch, S., Darkow, I. L. and Gracht, H. A. (2015), Opportunities for Social Enterprise in Germany - Evidence from an Expert Survey, Technological Forecasting and Social Change, Vol. 90, pp. 635-646.

Hackett, M. T. (2010), Challenging Social Enterprise Debates in Bangladesh. Social Enterprise Journal, Vol. 6 No.3, pp. 210-224.

Hackett, M. T. (2010), Challenging Social Enterprise Debates in Bangladesh, Social Enterprise Journal, Vol. 6 No.3, pp. 210-224.

Hall, K., Miller, R. and Millar, R. (2012), Jumped or Pushed: What Motivates NHS Staff to Set Up a Social Enterprise? Social Enterprise Journal, Vol. 8 No. 1, pp. 49-62.

Jiao, H. (2011), A Conceptual Model for Social Entrepreneurship Directed Toward Social Impact on Society, Social Enterprise Journal, Vol. 7 No.2, pp. 130-149.

Johnson, S. (2000), Literature Review on Social Entrepreneurship. Available at: www.bus.ualberta.ca/ccse/Publications/Publications/Lit._Review_SE_November_2000. $\underline{\mathrm{rtf}}$

Moreau, C. and Mertens, S. (2013), Managers' Competences in Social Enterprises: Which Specificities? Social Enterprise Journal, Vol. 9 No.2, pp. 164-183.

O'Shaughnessy, M., Casey, E. and Enright, P. (2011), Rural Transport in Peripheral Rural Areas: The Role of Social Enterprises in Meeting the Needs of Rural Citizens, Social Enterprise Journal, Vol.7 No.2, pp.183-190.

Overall, J., Tapsell, P. and Woods, C. (2010), Governance and Indigenous Social Entrepreneurship: When Context Counts. Social Enterprise Journal, Vol.6 No.2, pp. 146161. 
Rajput, N. and Chopra, P. (2014), Social Entrepreneurship and Social Sustainability: An Analytical Study. Global Journal of Finance and Management, Vol. 6 No.9, pp. 961-966.

Robinson, J. A., Mair, J. and Hockerts, K. (Eds) (2009), International Perspectives of Social Entrepreneurship, Palgrave, London.

Sawmy, M. V. (2015), Growing Inclusive Business Models in the Extractive Industries: Demonstrating a Smart Concept to Scale Up Positive Social Impacts, The Extractive Industries and Society, Article In Press.

Short, J., Moss, T. and Lumpkin, G. (2009), Research in Social Entrepreneurship: Past Contributions and Future Opportunities, Strategic Entrepreneurship Journal, Vol. 3 No.2, pp. 161-194.

Simmons, R. (2008), Harnessing Social Enterprise for Local Public Services: The Case of New Leisure Trusts in the UK, Public Policy and Administration, Vol. 23 No.3, pp. 177-202.

Sodhi, M. M. and Tang, C. S. (2011), Social Enterprises as Supply-Chain Enablers for the Poor, Socio-Economic Planning Sciences, Vol. 45 No4, pp. 146-153.

Thompson, J. (2011), Reflections on Social Enterprise and the Big Society, Social Enterprise Journal, Vol. 7 No.3, pp. 219-223.

Yu, X. M. (2011), Social Enterprise in China: Driving Forces, Development Patterns and Legal Framework, Social Enterprise Journal, Vol.7 No.1, pp. 9-32.

Defourny.J and Kim.S.Y (2011), Emerging models of social enterprise in Eastern Asia: a crosscountry analysis, Social Enterprise Journal Vol. 7 No. 1, 2011, pp. 86-111. 